Apidologie, 1985, 16 (4), 369-384

\title{
SURVIVAL, BEHAVIOR AND COMB CONSTRUCTION BY HONEY BEES, APIS MELLIFERA, IN ZERO GRAVITY ABOARD NASA SHUTTLE MISSION STS-13 ${ }^{(1)}$
}

\author{
J.D. VANDENBERG *, D.R. MASSIE **, H. SHIMANUKI *, \\ J.R. PETERSON $* * *$ and D.M. POSKEVICH $* * * *$ \\ * Plant Protection Institute, Bioenvironmental Bee Laboratory and \\ *: Sensors and Control Systems Group, Instrumentation Research Laboratory \\ U.S.D.A., Agricultural Research Service, Beltsville, Maryland 20705 \\ **:* Space and Strategic Avionics Division \\ Honeywell, Incorporated, Clearwater, Florida \\ :s:s: Waverly Central High School, Waverly, Tennessee \\ (Current Address : U.S. Army, Aberdeen Proving Grounds, Maryland)
}

\begin{abstract}
SUMMARY
An experiment to determine survival, behavior and comb building activity of bees at zero gravity $(0 \mathrm{~g})$ was conducted through the Shuttle Student Involvement Program (S.S.I.P.). A bee enclosure module (B.E.M.) was designed to hold ca 3400 worker bees and a queen for 7 days during a NASA Space Shuttle mission in April 1984. Honey bees at $0 \mathrm{~g}$ survived with low mortality, flew within a small flight chamber in the B.E.M., constructed ca $200 \mathrm{~cm}^{2}$ of comb and stored sugar syrup within it. The queen laid ca 35 eggs within newly constructed comb but these did not survive transfer to a hive upon their return to earth. The geometry of comb pieces built at $0 \mathrm{~g}$ was compared with comb from an early B.E.M. trial at one gravity $(1 \mathrm{~g})$ and from a normal hive. Cell densities, depths, diameters and wall thicknesses were all similar whether built at $0 \mathrm{~g}$ or $1 \mathrm{~g}$. Cell angles were also similar but did not angle consistently «downward» when built at $0 \mathrm{~g}$.
\end{abstract}

\section{INTRODUCTION}

The Shuttle Student Involvement Program (S.S.I.P.) is administered by the National Aeronautics and Space Administration (N.A.S.A.) and the National Science Teachers Association for the purpose of encouraging young scientists to

(1) Mention of a proprietary name is for the benefit of the reader and does not constitute endorsement by the U.S.D.A. 
pursue projects that may be carried out during N.A.S.A. Space Shuttle missions. Honeywell, Incorporated, has been a sponsor for several of these projects. Proposals are reviewed by a panel of experts and student winners are chosen to have their experiments flown on the Shuttle, depending upon available space and flight schedules. One of us (D.M.P.) was such a winner and was allowed to have his experiment, designed to obtain and analyze honey comb built by bees at zero gravity $(0 \mathrm{~g})$, flown on Shuttle flight number STS-13 (Mission 41-C). A report of the project (being prepared by J.R.P. and D.M.P.) will be submitted to S.S.I.P.

Comb construction by bees in enclosures depends upon the presence of a queen and adequate food supplies (DARCHEN, 1959 ; Freudenstein, 1960). A gravity sense organ was identified by LINDAUER and NEDEL (1959). Preventing the function of this organ (by sealing the head in place with paraffin) resulted in disorientation on the part of the bees. The influence of gravity receptors on comb building has been studied by Lindauer and Martin (1969). Sealing the bristles involved in gravity sensing, between the head and thorax, prevented comb construction. GoNTARSKI (1949) demonstrated that bees compensate for the effects of various centrifugal forces in comb construction. The vertical orientation of combs was determined by the direction and strength of the force applied.

The objectives of this study were to monitor survival and behavior of bees in $0 \mathrm{~g}$ and to compare the geometry of comb built at $0 \mathrm{~g}$ with that of comb built by bees at one gravity ( $1 \mathrm{~g})$.

\section{MATERIALS AND METHODS}

Approximately $3400(0.45 \mathrm{~kg})$ worker bees were introduced with a caged queen into each of two Bee Enclosure Modules (B.E.M., Fig. 1) on 5 April 1984. The queen cage was plugged with a mixture of powdered sugar and water which the workers consumed to effect her release. The modules were constructed of aluminium with a clear plastic top and contained a feeder trough, three wooden frames, a small flight chamber, a ventilation hole, a fan and two temperature probes. The dimensions of each B.E.M. were approximately $11.75 \mathrm{~cm} \times 38.10 \mathrm{~cm} \times 45.72 \mathrm{~cm}$. One frame contained drawn brood comb $(7.5 \times 7.5 \mathrm{~cm})$, and the other two contained plain wax sheets (unembossed foundation) of the same dimensions. One frame had ca $110 \mathrm{~g}$ Beltsville Bee Diet (1) attached at one side. The feeder measured ca $7.5 \times 7.5 \times 30.5 \mathrm{~cm}$ and containcd ca $1.67 \mathrm{I}$ of a mixture of water, sucrose and agar (166:120:1). The agar gave the mixture a semi-solid consistency necessary for $0 \mathrm{~g}$.

One B.E.M. with bees was placed aboard the shuttle at Kennedy Space Center (K.S.C.), Cape Canaveral, Florida, on 5 April for launch on 6 April. The other B.E.M., similarly loaded with bees, was kept at Johnson Space Center (J.S.C.), Houston, Texas, during the mission. The B.E.M. at J.S.C. was centrifuged briefly on 6 April to simulate launch and ascent conditions. An earlier trial with bees in a similar B.E.M. at $1 \mathrm{~g}$ was conducted in September 1983 at J.S.C. under similar conditions. 


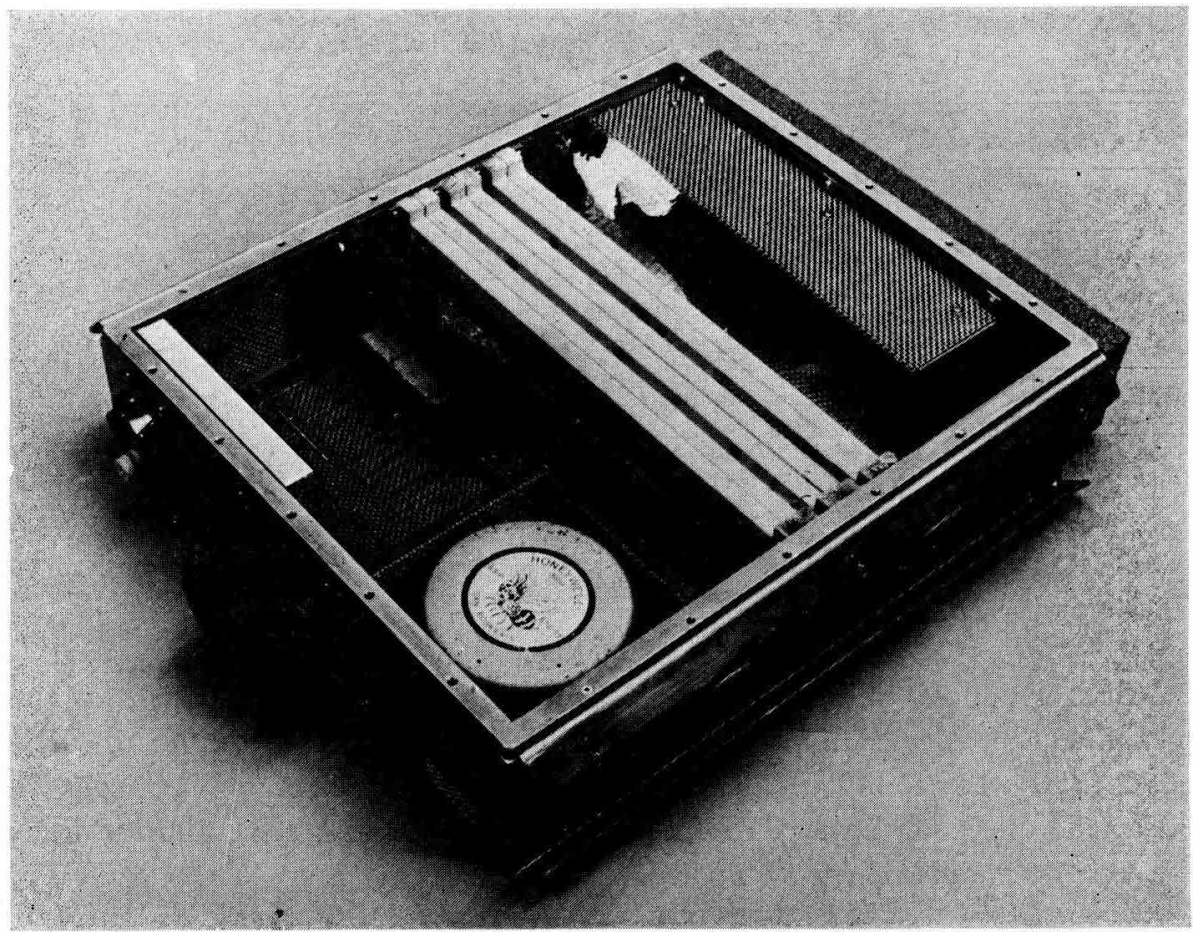

FIG. 1. - The Bee Enclosure Module

Length $=46 \mathrm{~cm}$. (A portion of comb piece number 1, Table 1, can be seen upper left).

The B.E.M. on board STS-13 was observed at four different times by crew members. On 6 April, $9 \mathrm{~h}$ after launch, the bees were noted as alive. On 9 and 11 April video recordings of the bees and observations of their behavior were made. On 13 April final visual observations were made. The B.E.M. at J.S.C. was monitored by J.S.C. personnel several times during the study.

Bees from the B.E.M. at J.S.C. were removed on 12 April. Bees in the B.E.M. on board STS-13 landed at Edwards Air Force Base, California, on 13 April and, while still in their B.E.M., accompanied the flight ${ }^{*}$ crew back to J.S.C. on the same day. They were removed from their B.E.M. on 14 April.

Six pieces of comb were used for estimating various geometric parameters (Table 1) : two pieces built without foundation and attached to the plastic top of the B.E.M. and one in a wooden frame built by bees at $0 \mathrm{~g}$, one piece built without foundation and one in a frame from the $1 \mathrm{~g}$ trial of September 1983 (very little comb was built by the bees at J.S.C. during the STS-13 flight), and one piece made from embossed foundation by bees at Beltsville, Maryland. Several measures of comb geometry were made. The number of cells per $\mathrm{dm}^{2}$ was estimated using photographs of each comb piece. Cell depths were estimated by measuring the distance of movement required to focus a video camera first on the top of the cell and then on the bottom of the cell. Cell wall thicknesses and inside diameters were estimated using a magnified video-image digitizer. Cell angles, the inclination of the cells from the plane perpendicular to the comb midrib, were estimated with a video camera by measuring the angle, in degrees (deg), at which an individual could look straight down into the cell. 
TABL. 1. - Comb pieces analyzed and their sources

\begin{tabular}{|c|c|c|}
\hline Comb Piece & Source & Foundation \\
\hline $\begin{array}{l}1 \\
2 \\
3 \\
5 \\
6\end{array}$ & $\begin{array}{lll}0 & \mathrm{~g} & \text { B.E.M. a } \\
0 & \mathrm{~g} & \text { B.E.M. } \\
0 & \mathrm{~g} & \text { B.E.M. } \\
1 & \mathrm{~g} & \text { B.E.M. } \\
\text { hive }\end{array}$ & $\begin{array}{c}\text { none } \\
\text { none } \\
\text { unembossed } \\
\text { unembossed } \\
\text { embossed }\end{array}$ \\
\hline
\end{tabular}

a B.E.M. = Bee Enclosure Module, see Materials and Methods and Fig. 1.

\section{RESULTS}

Bees within the B.E.M.s survived their week of confinement with low mortality. Ca 120 dead bees were recovered from the B.E.M. on board STS-13 and ca 350 were found in the B.E.M. at J.S.C. Approximately 35 eggs were laid by the queen on board STS-13. These eggs failed to hatch following transfer with bees to standard hive equipment near J.S.C.

Several observations were contributed by the flight crew of STS-13. Worker bees were observed crawling on the sugar syrup mixture and feeding directly from it. The bees were observed fanning their wings in a group near the air inlet (upper right of Fig. 1). Other clusters of bees extended from the sugar source to the area of active comb construction (upper left of Fig. 1). Dead bees were removed from the cluster by other workers and deposited in the fan area (lower right of Fig. 1). Bees were observed to engage in short flights : on 9 April some bees collided with the walls of the chamber (lower left of Fig. 1), but on 13 April bees engaging in directed flights avoided such collisions.

Temperatures within the 0 g B.E.M. were near $26^{\circ} \mathrm{C}$ in both the flight chamber and the cluster at the start of the experiment (6 April). By 9 April the temperature within the cluster was near $31^{\circ} \mathrm{C}$. In the 1 g B.E.M. at J.S.C., the temperature was $21^{\circ} \mathrm{C}$ for the first part of the experiment. To help raise the temperature, the air inlet was closed and then the temperature near the cluster increased to $29^{\circ} \mathrm{C}$. The temperature within the 1 g B.E.M. at J.S.C. in September 1983 was $32^{\circ} \mathrm{C}$ within the cluster.

Approximately $200 \mathrm{~cm}^{2}$ of comb was produced by the bees at $0 \mathrm{~g}$ (Figs. 1-3). Very little comb was built by the bees at J.S.C. during the STS-13 flight period. Bees in the $1 \mathrm{~g}$ trial of September 1983 produced in excess of $200 \mathrm{~cm}^{2}$ (Fig. 4). 


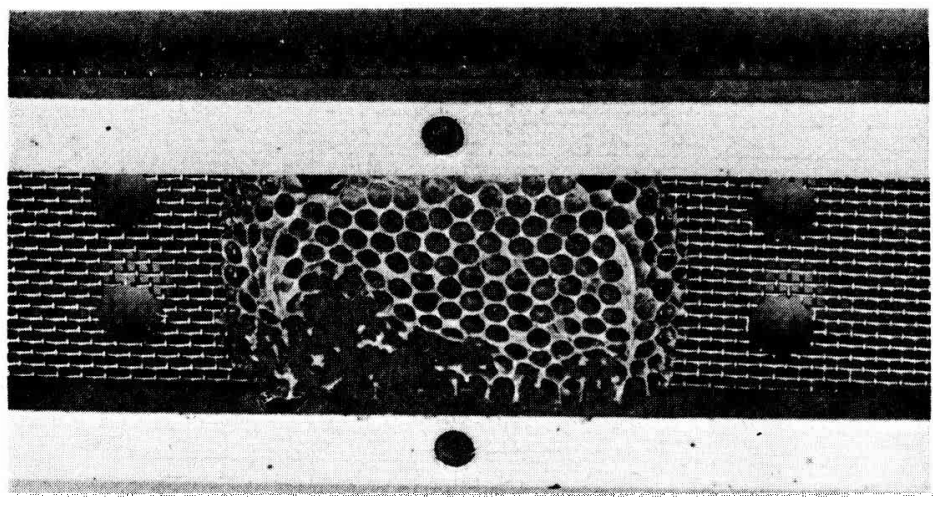

Fig. 2. - Comb piece built from unembossed wax foundation at zero gravity Frame height $=7.6 \mathrm{~cm}$. (This is piece number 3 , Table 1 ).

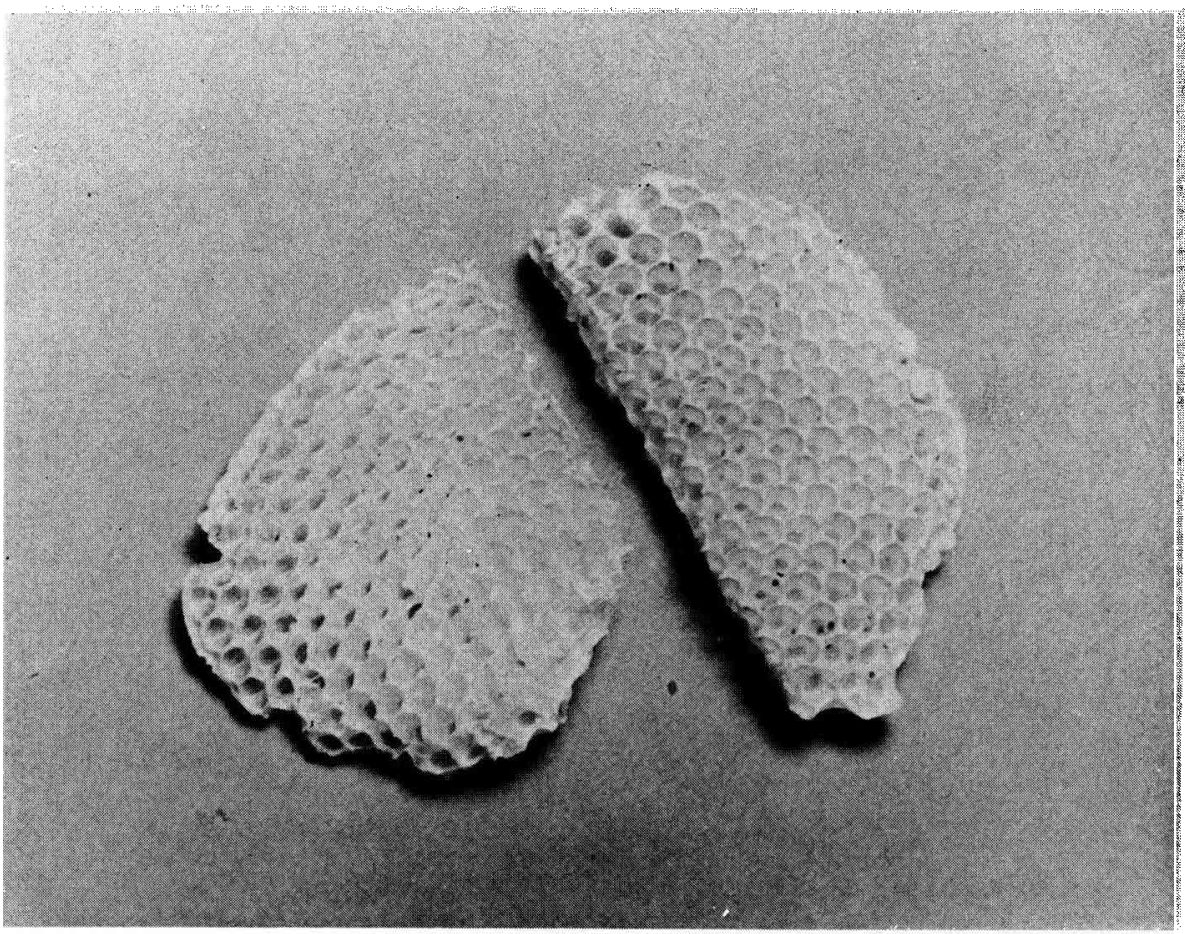

FIG. 3. - Comb pieces constructed without foundation wax at zero gravity

Long dimension of comb piece on the right $=8.6 \mathrm{~cm}$. (The comb piece on the right is number 2, Table 1). 


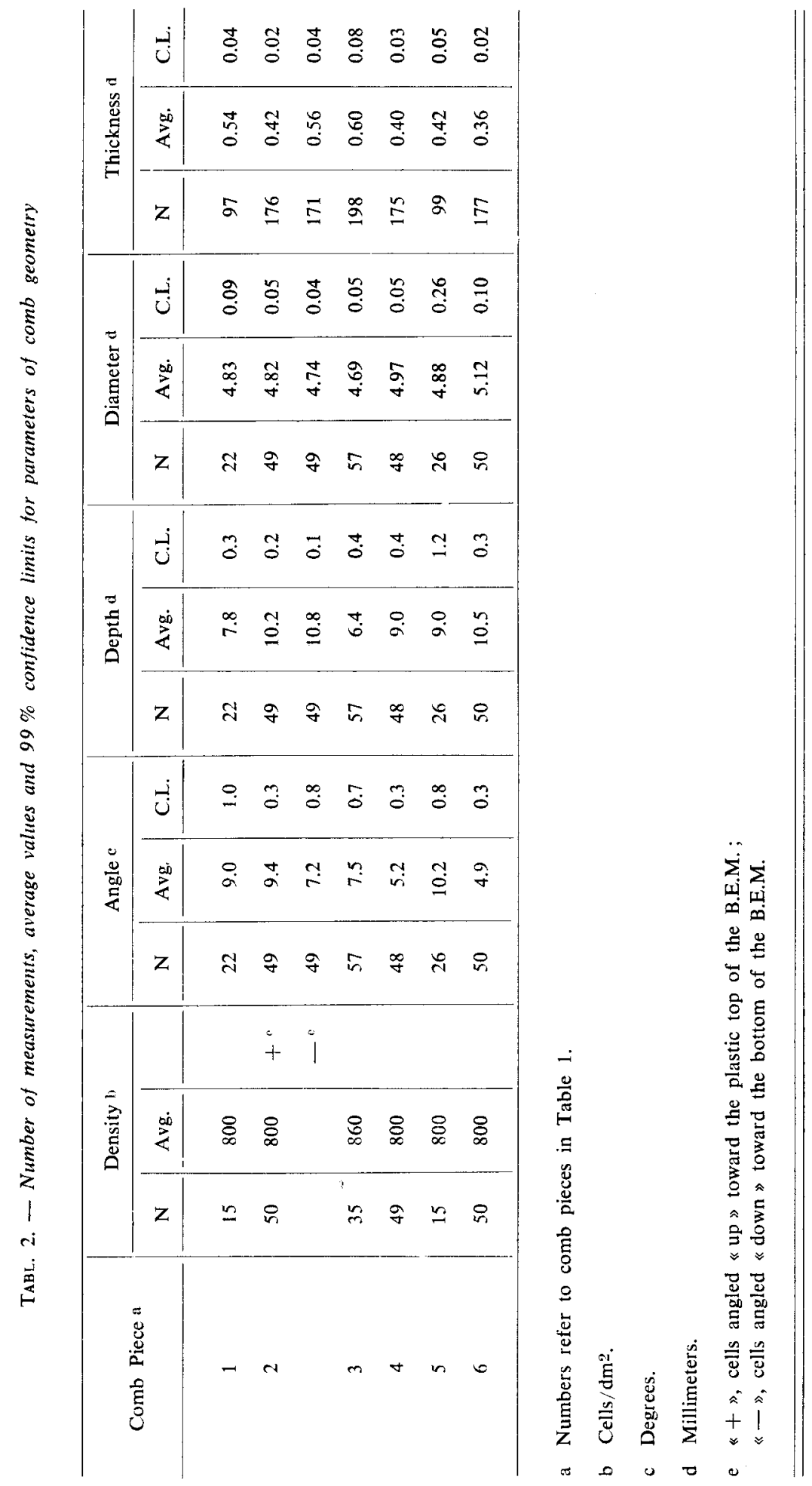




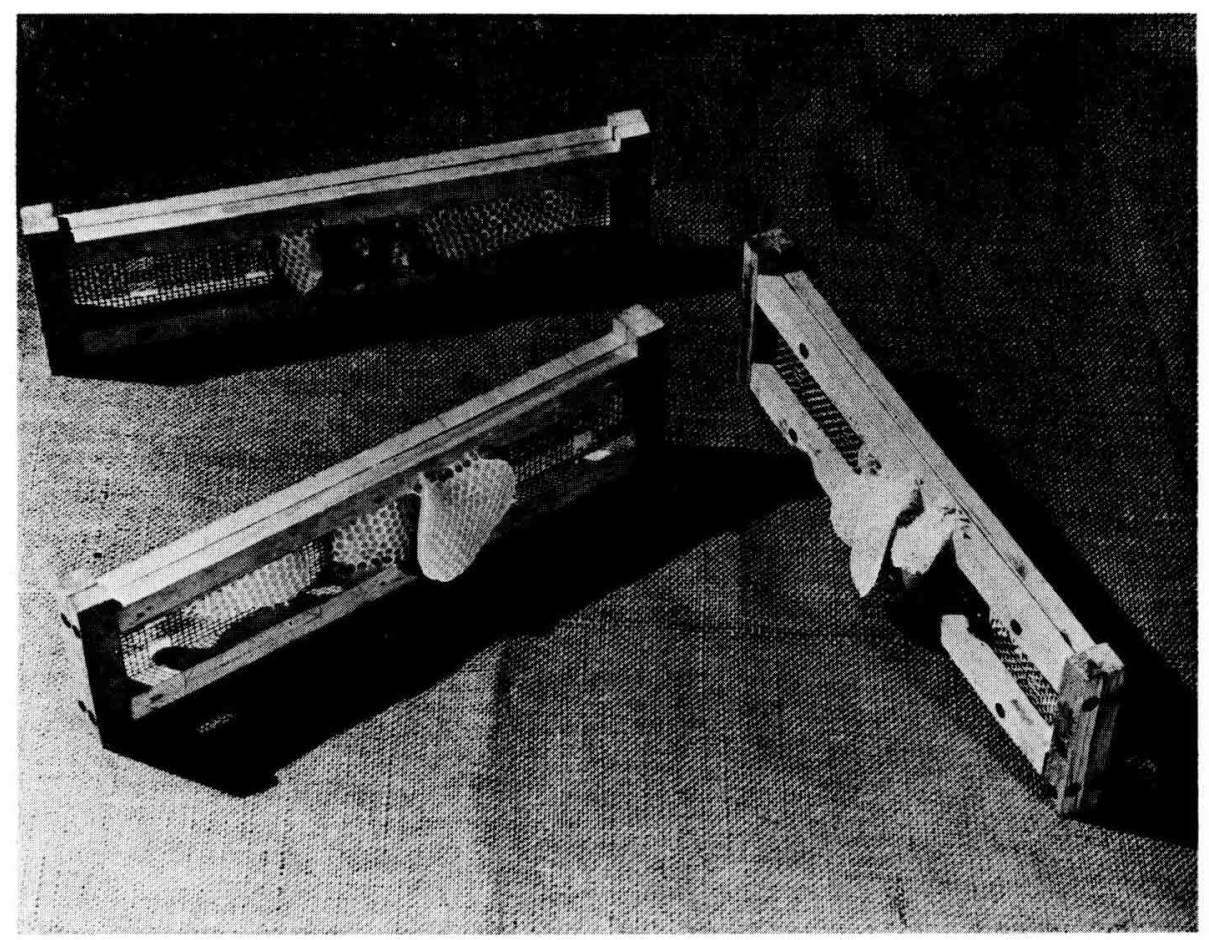

FIG. 4. - Comb constructed within a Bee Enclosure Module during the trial at one gratity Table 1).

Frame height $=7.6 \mathrm{~cm}$. (The frame in the left foreground contains pieces number 4 and 5 ,

Various parameters of comb geometry are presented in Table 2. Average cell densities were neariy identical for all comb pieces ( 800 cells $/ \mathrm{dm}^{2}$ ) except for comb drawn from foundation at $0 \mathrm{~g}$ (piece number 3 ). These cells were more densely spaced (average 860 cells $/ \mathrm{dm}^{2}$ ) than those of other comb pieces. Diagrams of percentage frequency distributions, by comb piece, for cell angle, depth, diameter and wall thickness are shown in Figs. 5-8.

For all comb pieces built at $1 \mathrm{~g}$, the cells on each comb face were parallel and thus had angies all within the same plane. For the two pieces buiit at $0 \mathrm{~g}$ without foundation, all cells on any one side of the comb had angles in the same plane. However, for the larger piece (piece on the right of Fig. 3, and number 2, Tables 1 and 2 and Fig. 5), cells on one side were angled « up » (labeled «+ » in Table 2) toward the plastic top of the B.E.M. where the piece was attached. Cells on the other side were angled « down» (labeled «_» in Table 2) toward the floor of the B.E.M. Cells angled «up» had a higher average angle than 
those angled «down» (9.4 deg and $7.2 \mathrm{deg}$, Table 2$)$. The piece of comb drawn from unembossed wax at $0 \mathrm{~g}$ (Fig. 2 and number 3, Tables 1 and 2, Fig. 5) displayed a wide range of angles which were mostly oriented «up » toward the plastic top of the B.E.M. This piece appeared to have been started by the bees from the floor of the B.E.M.

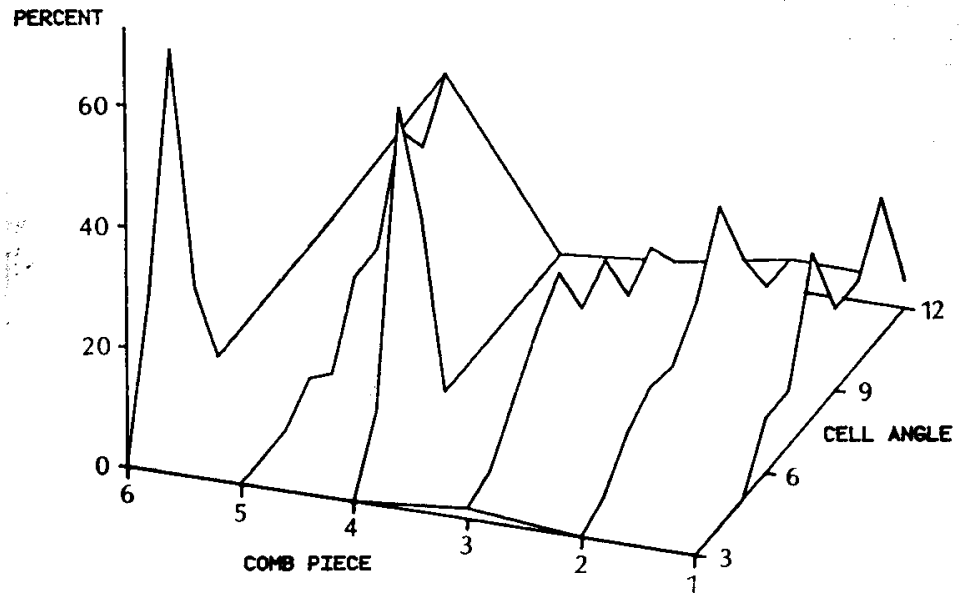

FIG. 5. - Distribution of cell angles (degrees)

Comb piece numbers are listed in Table 1. Y-axis represents the percentage of total observations for each angle measured.

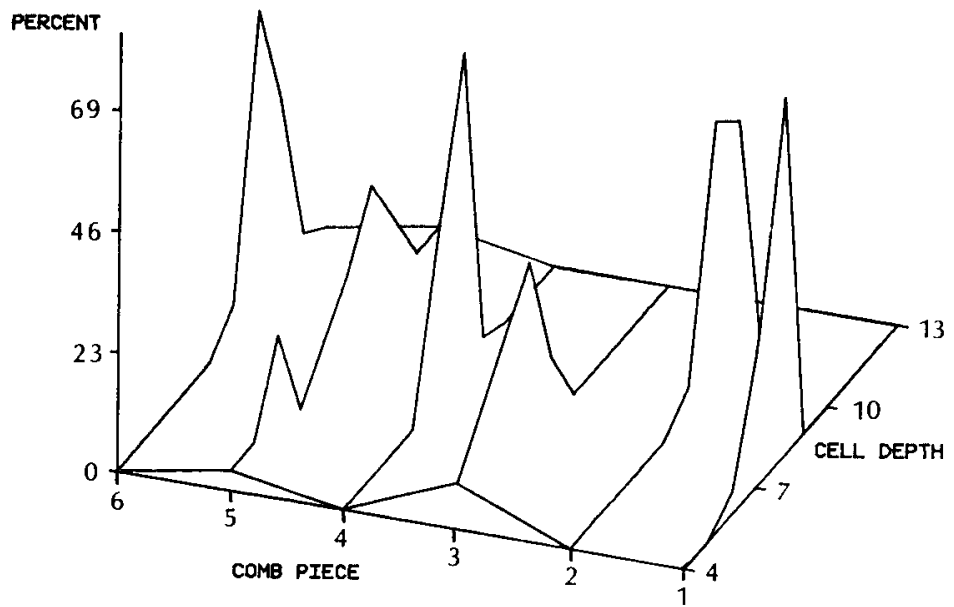

Fig. 6. - Distribution of cell depths ( $\mathrm{mm}$ )

Comb piece numbers are listed in Table 1. Y-axis represents the percentage of total observations for each cell depth measured. 
construction, but temperatures ranging from $21^{\circ} \mathrm{C}$ to $29^{\circ} \mathrm{C}$ in the $1 \mathrm{~g}$ control B.E.M. at J.S.C. were not. GARY (1975) reports that temperatures from 33 to $36^{\circ} \mathrm{C}$ are needed for wax secretion. Although the temperature probe indicated 31 to $32{ }^{\circ} \mathrm{C}$, the bees involved in comb construction could easily have had elevated temperatures within the cluster which enabled wax secretion.

Most of the comb constructed by the bees at $0 \mathrm{~g}$ was near to the sugar source. The comb pieces were attached to the top of the B.E.M. approximately parallel to one another. However the faces of the comb pieces angled toward one another and were attached near the bottom of the B.E.M. Perhaps the bees used the nearby wooden frame and feeder trough to orient the attachment of their combs, but the combs were not oriented vertically with respect to the plastic top of the B.E.M.

The piece of comb drawn from unembossed wax at $0 \mathrm{~g}$ was further removed from the sugar source (bottom frame in Fig. 1). The cells on this comb were not drawn to their full depth and perhaps this is due to their distance from the food. Comb constructed by bees in the 1 g B.E.M. trial at J.S.C. (in September, 1983), however, was located on all of the frames (Fig. 4).

Our measurements of comb pieces are similar to those made by other workers. TABER and OWINS (1970) found 814 cells/dm² and DADANT (1975) listed 857 cells $/ \mathrm{dm}^{2}$. Our estimates were 800 cells $/ \mathrm{dm}^{2}$ for most comb pieces and 860 cells $/ \mathrm{dm}^{2}$ for comb piece number 3 (Table 2 ).

Cell angles have been measured by several previous workers. VoGT (1911) found angles up to $16 \mathrm{deg}$ and cited Huber as finding an average of 4 to $5 \mathrm{deg}$ but a maximum of greater than $20 \mathrm{deg}$. TABER and OWENS (1970) measured cells with an average of $5 \mathrm{deg}$ and a range of 0 to $13 \mathrm{deg}$. Dadant (1975) reported angles ranging from 9 to $14 \mathrm{deg}$. Our measurements ranged from 4 to $13 \mathrm{deg}$ and the averages for the $6 \mathrm{comb}$ pieces ranged from 5 to $10 \mathrm{deg}$.

Average cell depths of 6 to $10.5 \mathrm{~mm}$ were estimated from our comb pieces and the range of measurements was 4 to $13 \mathrm{~mm}$. An average of $12.11 \mathrm{~mm}( \pm 0.29$, standard deviation, sd) was found by TABER and OWENS (1970).

Cell diameters determined by VogT (1911) ranged from 4.92 to $5.50 \mathrm{~mm}$. TABER and OWENS (1970) found $5.21 \mathrm{~mm}$ ( $\pm 0.46 \mathrm{sd})$ as the average «cell size 》 (= diameter ?). Our estimates of average inside diameter ranged from 4.76 to $5.12 \mathrm{~mm}$. These are smaller than those of the other workers but since their measurements may have included portions of the adjacent cell walls, the inside diameters are in close agreement.

Cell wall thicknesses have been noted to be greater at the top of the cell (0.2 to $0.4 \mathrm{~mm}$ by VogT, 1911) and much thinner below $(0.08$ to $0.09 \mathrm{~mm})$. 
DARWIN (1872) reported a wall thickness of $0.072 \mathrm{~mm}$; apparently his measurements were not taken near the top of the cells. TABER and OWENS (1970) must have measured cell wall thicknesses at the top of the cell to obtain estimates of 0.38 to $0.64 \mathrm{~mm}$. Our averages for the 6 comb pieces are within this range, between 0.36 and $0.60 \mathrm{~mm}$, although our range of measurements extended to $1.5 \mathrm{~mm}$ at $1 \mathrm{~g}$ and to $3.6 \mathrm{~mm}$ at $0 \mathrm{~g}$. This last extreme came from the comb piece depicted in Fig. 2, where considerable variability in cell wall thickness can be seen.

The importance of prior learning on the ability of bees within the B.E.M.s to construct comb must not be overlooked. The bees used were approximately 15 days old at the start of the study and may have been involved in comb construction prior to this experiment. This may have influenced the orientation of the side walls of the cells (MORSE, 1983). The reason for the variable orientation of cell side walls seen on comb drawn from unembossed foundation wax is unknown. Other influences of prior experience on comb construction are also unknown.

Although we were unable to replicate these experiments, some conclusions may be drawn from the data presented here. These bees were able to function in an apparently normal manner at $0 \mathrm{~g}$ as evidenced by their behavior and survival. Some disorientation during flight was observed, however. The queen laid eggs in cells constructed by the bees at $0 \mathrm{~g}$. Wax secretion and comb construction took place. (Wax glands of bees at $0 \mathrm{~g}$ or $1 \mathrm{~g}$ were not examined). Although the variation of cell angles with the side of the comb gives a clear indication of disorientation of the bees, other aspects of comb geometry were similar to those of comb built by bees on earth. The considerable variability evident in one comb piece constructed at $0 \mathrm{~g}$ (fig. 2) may also have been due to disorientation of the bees at $0 \mathrm{~g}$.

The opportunity to repeat this experiment or design a related one for a future shuttle mission may be unlikely. However, it would be of interest to continue such an experiment for a longer period of time to enable eggs laid by the queen to continue development at $0 \mathrm{~g}$. Placement of the sugar source closer to the foundation wax would likely have increased the use of this wax by bees involved in comb construction. A larger flight chamber would allow more detailed observations on orientation of bees attempting flight at $0 \mathrm{~g}$. These and many other possibilities could be explored under conditions of $0 \mathrm{~g}$. 


\section{ACKNOWLEDGEMENTS}

Many people helped make this experiment a success and we wish to thank the following. Andrew S. Hendrix (as D.M.P.'s high school science teacher) was especially helpful to D.M.P. in the early phases of this study. Mel E. Coplin, of Coplin Bee Farms, Arcadia, Texas, provided bees and advice on the planning and conduct of the experiment. Back-up bees were provided by E. John Gregory of Ambrose Farms, Inc., Miami, Florida, and were also offered by Frank Wristey of Cocoa, Florida, and Jack Edwards of Titusville, Florida. The help of Marianna Peterson was essential before, during and after the experiment. Albert H. Crews, Neil W. Christre and Ruben Zavala provided help at J.S.C. As the NASA Manager of Student Experiments at J.S.C., John T. JACKSON provided guidance in the planning of the experiment and the coordination required to get the experiment approved by NASA, assigned to the STS-13 flight and flown on STS- 13 . Finally we acknowledge the crew of STS-13, particularly mission specialists George D. NeLSON and James D. VAN Hoften, without whose expertise and assistance this study would not have been possible.

Drs. D. Caron, R. Morse, F. Ruttner and G. Waller reviewed a draft of this paper and all made helpful comments. We are grateful to them.

\section{RÉSUME \\ SURVIE, COMPORTEMENT ET CONSTRUCTION DE RAYON \\ PAR LES ABEILLES (APIS MELLIFICA L.) \\ EN ETAT D'APESANTEUR LORS DE LA MISSION SPATIALE STS-13 DE LA NASA}

Une expérience a été menée dans le cadre du NASA Shuttle Student Involvement Program afin de déterminer la survie, le comportement et l'activité de construction des abeilles en état d'apesanteur (gravitation $0 \mathrm{~g}$ ) lors de la mission spatiale STS-13.

Environ 3400 ouvrières adultes accompagnées d'une reine ont été placées dans chacun des deux containers (Fig. 1). On leur a fourni du sirop de sucre, du succédané de pollen, des feuilles de cire lisse (non gaufrée) et des morceaux de rayons de cire. L'un des deux containers fut emporté par la navette spatiale, l'autre resta au Centre Spatial Johnson de Huston, Texas.

Les abeilles ont survécu à leurs 7 jours passés dans l'espace en ne présentant qu'une faible mortalité. La reine a pondu un petit nombre d'œufs et les ouvrières ont construit et stocké du sirop dans les cellules (Fig. 2 et 3 ). Les observations faites par les spécialistes de la mission concernant la construction, les activités de vol et de nettoyage indiquent un comportement normal des abeilles. Les abeilles restées au sol n'ont pas construit de rayon, mais lors d'un essai préliminaire, dans des conditions semblables, les abeilles avaient construit (Fig. 4) et s'étaient comportées normalement dans le container.

La géométrie du rayon construit en apesanteur est normale, comparée à celle du rayon construit par les abeilles lors de l'essai préliminaire ou dans une ruche normale (Tabl. 1 et 2). D'autres chercheurs ont obtenu des données semblables concernant la géométrie du rayon. Néanmoins les axes des cellules construites en apesanteur n'ont pas tous été orientés vers le bas.

Les oufs pondus par la reine en apesanteur n'ont pas survécu après leur transfert dans une ruche, une fois revenus sur terre. Mais il ne faut pas oublier qu'ils ont été soumis à des conditions de milieu inconnues, qui ont pu agir sur leur survie.

Le fait que les abeilles dans le container n'aient pas construit de rayon peut être dû aux faibles températures de la grappe enregistrées dans le container $\left(21\right.$ à $\left.29^{\circ} \mathrm{C}\right)$. Des températures de $31^{\circ} \mathrm{C}$ en apesanteur et de $32^{\circ} \mathrm{C}$ lors de l'essai préliminaire sur terre ont été suffisantes pour favoriser la construction de rayons. 
Les futures expériences spatiales pourraient inclure des abeilles à tous les stades de développement afin de déterminer l'effet d'apesanteur sur leur survie et leur développement. Des observations plus détaillées sur le comportement de vol et de butinage pourraient être faites en utilisant un container avec un compartiment de vol plus grand et des sources de nourriture éloignées.

\section{ZUSAMMENFASSUNG}

\section{ÜBERLEBEN, VERHALTEN UND WABENBAU VON HONIGBIENEN (APIS MELLIFERA) BEI SCHWERELOSIGKEIT WAHREND DER NASA SHUTTLE MISSION STS-13}

Im Rahmen des National Aeronautics and Space Administration's (NASA) Shuttle Student Involvement Program wurde ein Experiment durchgeführt, um Überleben, Verhalten und WabenbauAktivität von Honigbienen bei Schwerelosigkeit (Gravitation $0 \mathrm{~g}$ ) an Bord der NASA Shuttle Mission STS-13 zu untersuchen.

Ungefähr 3400 adulte Arbeitsbienen mit Königin wurden in je einen von zwei Behältern gebracht (Fig. 1). Sie wurden mit Zuckersyrup, Pollenersatz sowie mit Stücken von glatter (ungeprägter) Wachsmittelwand und ausgebauter Wabe versorgt. Ein Behälter machte den Flug mit dem Shuttle mit, der andere verblieb am Johnson Space Center in Huston, Texas,

Die Bienen überlebten ihre 7 Tage im Weltraum mit nur geringer Mortalität. Die Königin legte eine kleine Zahl von Eiern und die Arbeitsbienen errichteten Wabenbau und lagerten Zuckersyrup darin ab (Fig. 2-3). Die Beobachtungen der Weltraumfahrer über Wabenbau und Flug- und Reinigungsaktivitäten zeigten ein normales Verhalten der Bienen. Das auf der Erde verbliebene Kontrollvolk errichtete zwar keinen Wabenbau, aber bei eınem früheren Versuch unter ähnlichen Bedingungen bauten die Bienen (Fig. 4) und sie verhielten sich in dem Behälter normal.

Im Vergleich zu dem Wabenbau aus dem früheren Versuch und von normalen Bienenvölkern war die Geometrie der Waben, die unter den Bedingungen der Schwerelosigkeit gebaut wurden, normal (Tab. 1 und 2). Ahnliche Maße der Wabengeometrie wurden auch von früheren Untersuchern angegeben. Die Achsen der unter $0 \mathrm{~g}$ Gravitation errichteten Zellen waren jedoch nicht mit der üblichen Regelmäßigkeit nach oben gerichtet.

Die von der Königin während der Schwerelosigkeit abgelegten Eier überlebten nach Rückkehr zur Erde die Überführung in ein Volk nicht. Es ist aber zu bedenken, daß sie unbekannten Umwelteinflüssen ausgesetzt waren, die ihr überleben beeinflußt haben könnten.

Das Ausbleiben einer Bautätigkeit bei dem Kontrollvolk auf der Erde kann seine Ursache in der niedrigen Temperatur der Bienentraube gehabt haben, die aus dem Behälter aufgezeichnet wurde $\left(21-29^{\circ} \mathrm{C}\right)$. Temperaturen von $31^{\circ} \mathrm{C}$ bei $0 \mathrm{~g}$ und von $32^{\circ} \mathrm{C}$ bei dem früheren Versuch auf der Erde waren hingegen hoch genug, um den Wabenbau zu fördern. Künftige Shuttle-Experimente könnten Bienen von allen Lebensstadien einschließen, um den Einfluß von $0 \mathrm{~g}$ Gravitation auf ihre Úberlebensfähigkeit und ihre Entwicklung zu bestimmen. Bei Benutzung eines Behälters mit größerem Flugabteil und einer weiter entfernten Futterquelle könnten eingehendere Beobachtungen über das Flug- und Sammelverhalten der Bienen gemacht werden.

\section{REFERENCES}

Dadant C.C., 1975. - Beekeeping equipment. In Dadant and Sons (eds.), The Hive and the Honey Bee. Dadant, Hamilton, Illinois, 303-328.

Darchen R., 1959. - Les techniques de construction chez Apis mellifica. Ann. Sci. Nat., Zool. I2th Ser., 1, 113-209. 
Darwin C., 1872. - The Origin of Species, 6th ed. Collier Books, Macmillan, New York (1962).

Freudenstein H., 1960. - Einfluss der Pollennahrung auf das Bauvermögen, die Wachsdrüsen und den Fettkörper der Honigbiene (Apis mellifera L.). Zool. Jahrb., 69, 95-124.

Gary N.E., 1975. - Activities and behavior of honey bees. In Dadant and Sons (eds.), The Hive and the Honey Bee. Dadant, Hamilton, Illinois, 185-264.

GONTARSKI, H., 1949. - Über die Vertikalorientierung der Bienen beim Bau der Waben und bei der Anlage des Brutnestes. Z. Vergl. Physiol., 31, 652-670.

Lindauer M., Martin H., 1969. - Special sensory performances in the orientation of the honey bee. Theoretical Physics and Biology (Proc. 1st Int. Conf. Theor. Phys. Biol.) North Holland, Amsterdam, 332-344.

Lindauer M., Nedel J.O., 1959. - Ein Schweresinnesorgan der Honigbiene. Z. Vergl. Physiol., 42, 334-364.

MORSE R.A., 1983. - Cell orientation and comb strength in honeybee colonies. Gleanings in Bee Culture, 111, 10, 14, 16, 18, 19.

Taber S., III, OWens C.D., 1970. - Colony founding and initial nest design of honey bees, Apis mellifera. Anim. Behav., 18, 625-632.

VoGT H., 1911. - Geometrie und ökonomie der Bienenzelle. Breslau : Trewendt und Granier. 